JoËLle Gaymu*, Peter EkAMPeR** AND GiJs Beets**

\title{
Who will be caring for Europe's dependent elders in 2030?
}

\begin{abstract}
As the population of Europe grows older, the problem of dependence is becoming an important issue. Can we predict the care needs of dependent older adults over the medium and long term? And, in particular, how will the burden of care be shared between family and professional carers? In this article, Joëlle GAYMU, Peter EKAMPER and Gijs BEETS examine these questions for nine European countries by projecting the future evolution - up to 2030 - of demographic trends among older adults that are already known (number of children), or largely predictable (marital status, parenthood, widowhood, etc.). Of course, the prevalence of dependence in years to come will be largely determined by the future health status of older people. Yet the demographic projections also indicate that the number of elders who have children and who survive longer with their partner will increase faster than the older population as a whole. Beyond its implications in terms of psychological and social support for older people, this factor should be taken into account when defining future care policies for the dependent population.
\end{abstract}

Throughout Europe, the population of over-75s will increase rapidly up to 2030. And although most people grow old in good health, the risk of physical and psychological dependence rises with advancing age. Hence, as the European population grows older, the care needs of dependent persons will increase in parallel. As new sets of generations reach old age, the volume and nature of their needs are liable to change, however. The elders of tomorrow will differ in many ways from those of today, in terms of health, marital status, living arrangements, etc., and these differences will reshape the future management of dependence. The numerical increase in the elderly population is not the only factor involved.

\footnotetext{
* Institut national d'études démographiques, Paris.

** Netherlands Interdisciplinary Demographic Institute, The Hague.

Translated by Catriona Dutreuilh.
} 
The type of assistance received by older people is closely linked to the type of household in which they live and, more broadly, their family environment. Spouses and children are the primary carers of dependent elders (Chappell, 1991; Walker et al., 1993), but when family members are absent or unavailable, demand for professional care increases. Indeed, dependent seniors living alone more often receive professional assistance than those living with a spouse or with other persons (Arber et al., 1988; Grundy, 2006; Martel and Légaré, 2001; Pickard et al., 2000). In France, for example, two-thirds of dependent elders living alone receive professional assistance, compared with half of those living with a spouse and $40 \%$ of those who share a dwelling with other family members (Breuil-Genier, 1998). Changes in the household structure of older people may thus modify their needs of assistance, with strong implications for policymakers. Such changes will also affect individual well-being. We know, for example, that persons living with a partner are better off financially, have a better state of health (Glaser et al., 1997) and are more socially integrated than those without a partner (Delbès and Gaymu, 2003a; De Jong Gierveld et al., 1997).

The factors associated with the living arrangements ${ }^{(1)}$ of older people have been widely studied (Pampel, 1992; Wolf, 1995; Palloni, 2001; Légaré and Martel, 2003; Tomassini et al., 2004; United Nations, 2005), and a very strong link between marital status and the household structure of older persons is observed. Practically all married seniors live with their spouse, while widows, widowers and divorcees, who have similar living arrangements, mostly live alone. Being more frequently widowed, women more often find themselves living alone, while men generally grow old with their spouse (United Nations, 2005; Delbès and Gaymu, 2006). Singles, for their part, are more likely to live in an institution (Dolinsky and Rosenwaike, 1988; Ricci, 1991; Grundy and Glaser, 1997; Carrière and Pelletier, 1995). Being in poor health or having no surviving children also have a major impact on living arrangements. They reduce residential autonomy and increase the likelihood of institutionalization (Angel and Himes, 1992; Soldo et al., 1990; Stinner et al., 1990; Désesquelles and Brouard, 2003). Last, research on the links between socioeconomic status and living arrangements shows that wealthier old people tend to cohabit less with family members and more often live alone (Pampel, 1992; Mc Garry and Schoeni, 2000).

The changes observed in recent decades have led to greater residential autonomy among older people. Across Europe, intergenerational coresidence is becoming less common, with elders more often preferring to stay in their own home, either alone or with their spouse (Michael et al., 1980; Murphy and Grundy, 1994; Ruggles, 2001). Many other contextual factors, such as growing urbanization, evolving family and social norms, development of home care services, etc. have contributed to this trend. These sociocultural aspects are key to explaining the geographical contrasts observed today (Iacovou, 2000; Glaser et al., 2004; Gaymu et al., 2006). In other words, Europeans with identical

(1) In this article the term "living arrangement" is used as a synonym of household structure. 
characteristics grow old in very different environments. Living alone or in an institution are the favoured options in northern countries, while intergenerational coresidence is preferred in the south (Pampel, 1992; Tomassini et al., 2004). In Portugal, for example, $59 \%$ of dependent ${ }^{(2)}$ widows aged 85 or over live with their family, compared with only $10 \%$ in the Netherlands.

This article presents demographic projections of the household structures of older adults up to 2030 in nine European countries, illustrating the wide variety of sociopolitical contexts in the different regions of Europe (Belgium, Czech Republic, England-Wales, Finland, France, Germany, Italy, Netherlands and Portugal) ${ }^{(3)}$. Following on from other recent research (Comas-Herrera et al., 2006; Pickard et al., 2000; Duée et al., 2005; Keefe et al, 2005), it aims to show how changes in the sociodemographic characteristics of older adults will affect their living arrangements and thereby modify the form and intensity of care needs. These projections take account of trends in the three most basic determinants of older people's living arrangements: marital status, health status and surviving children. They ignore changes in behaviour (changing nature of obligations between parents and children, preference for residential independence, social norms, etc.) as well as changes in eldercare policy. Though these changes are difficult to predict or to quantify, they will be discussed in detail.

After presenting the method and data used, we will focus on the family context, which depends to a large extent on the past marital and fertility histories of succeeding generations. Our aim is to determine whether dependent elders of tomorrow will be able to count more often than those of today on spouses and adult children to address their care needs. This will provide an initial measure of changes in the balance between professional and family care needs. Of course, living with a spouse and receiving support from a child when the need arises do not necessarily signify an absence of professional care needs, notably in the case of cognitive impairment. But people with no family support more often rely on professional care, as shown, for example, by the higher proportion of single elders living in institutions. We will then examine the living arrangements of persons who do not live with a spouse. The majority of older women are in this situation and, in most such cases, they live alone in their own homes. But as their health deteriorates, their domestic autonomy decreases and it becomes difficult or even impossible for them to remain at home without outside help. In this case, two options are open to them (and their family): moving in with a family member (generally a son or daughter) or entering an institution.

This article focuses exclusively on the population aged 75 and over, a critical threshold for the risks of widowhood and dependence.

(2) In this article, the terms "dependent", "with disabilities" and "in poor health" are used synonymously.

(3) These countries took part in the Future Elderly Living Conditions in Europe (Felicie) project funded by the European Commission. 


\section{Data and method}

The starting point for the results presented here was a first series of demographic projections by marital status that take account of all events liable to generate change over time and over cohorts. They were then used as a base for various derived projections. First, two different health status scenarios were introduced. The various sub-populations obtained were then broken down according to the existence or otherwise of a surviving child. Last, each of the sub-categories thus defined (by age, sex, marital status, health status and existence of a surviving child) were further sub-divided by type of household (living with spouse, alone, with other persons or in a collective household). These successive projections produced a detailed breakdown of the population by level of vulnerability: from persons in good health, living with a spouse and with a surviving child, to persons in poor health, living in an institution or alone in their home and with no surviving child. The results presented here concern the dependent population only. They were obtained in four main stages.

\section{Marital status transitions}

To project population by age, sex and marital status, the rates of transition between the various marital situations are needed, along with data on mortality levels and trends by marital status. The starting point is the population aged 45 or over on 1 January 2000. The changes observed over the ten previous years, based on data from the marriage, divorce and death registers ${ }^{(4)}$, were extrapolated up to 2030 on the basis of current trends. The mortality assumptions were adjusted in line with the projections issued by the various national statistical offices around the year 2000. Everywhere, it was assumed that women's life expectancy would increase more slowly than that of men. The matrices of transition between the various situations (deaths and marital status) were calculated with the LIPRO model (van Imhoff and Keilman, 1991). The results of these projections by marital status have been published (Kalogirou and Murphy, 2006) and Table 1 summarizes their main tendencies.

\section{Health status transitions}

Measuring the health status of the various European populations is a difficult challenge, and a range of data sources are used, including Europanel ${ }^{(5)}$, national health surveys and censuses. Europanel is one of the rare international sources which gives a measure based on a common question asked in each

(4) In all countries, life expectancy gains have been highest for married persons and divorce rates above age 45 have risen. Marriage rates have fallen everywhere except in Finland, France and the Netherlands.

(5) Multi-round survey conducted over eight successive years (1994-2001) among private households in European countries. 
Table 1. Marital structure of the dependent population in 2000 and 2030 by sex and age for all nine European countries* under a stable health scenario (\%)

\begin{tabular}{|c|c|c|c|c|c|c|c|c|c|c|}
\hline & \multicolumn{5}{|c|}{ Men } & \multicolumn{5}{|c|}{ Women } \\
\hline & Single & Married & Widowed & Divorced & Overall & Single & Married & Widowed & Divorced & Overall \\
\hline \multicolumn{11}{|c|}{ Age $75-84$} \\
\hline 2000 & 7 & 69 & 21 & 3 & 100 & 10 & 25 & 61 & 4 & 100 \\
\hline 2030 & 10 & 64 & 13 & 13 & 100 & 8 & 40 & 37 & 15 & 100 \\
\hline \multicolumn{11}{|c|}{ Age 85 or above } \\
\hline 2000 & 7 & 46 & 45 & 2 & 100 & 10 & 7 & 80 & 3 & 100 \\
\hline 2030 & 5 & 58 & 31 & 6 & 100 & 6 & 23 & 63 & 8 & 100 \\
\hline \multicolumn{11}{|c|}{ Age 75 or above } \\
\hline 2000 & 8 & 62 & 27 & 3 & 100 & 10 & 18 & 68 & 4 & 100 \\
\hline 2030 & 8 & 62 & 19 & 11 & 100 & 7 & 33 & 48 & 12 & 100 \\
\hline
\end{tabular}

country. However, comparisons of disability levels must be treated with caution, since certain divergences may reflect differences in interpretation of the question or in lifestyle rather than real contrasts in health status. Moreover, the survey only covers persons living in private households, thereby excluding the population living in institutions, which is strongly selected by marital and health status, but in ways which differ between countries. In view of these limitations, disability rates were not used in this article as pertinent indicators for measuring international disparities, and the comparative analyses only concern the relative size of the various categories within the sub-population of dependent persons.

To determine this sub-population, the following question is asked: "Are you hampered in your daily activities by any physical or mental health problem, illness or disability?" Persons who reply "severely" were selected to define the dependent population. Because the sample of unmarried persons in Europanel is very small, we used data on married individuals only. Their disability level by sex and age was estimated for each country, taking account of the institutionalized populations recorded in the censuses. Data from the various national health surveys were then used to analyse the differences between disability levels of widowed, single or divorced individuals and married ones. These differentials were then adjusted in line with the levels calculated for married individuals in Europanel.

With no clear trend available for the past (Robine et al., 2003), two possible health scenarios were defined for the future. In the first scenario, the disability levels by age and marital status remain constant. In this case, the overall 
number of dependent persons follows the same pattern as that of the general population, and the disparities between countries are above all a reflection of their specific demographic histories. Certain structural changes in the elderly population (higher educational level, less strenuous occupations) or behavioural changes (better risk awareness, improved diet and more healthy lifestyles) nonetheless suggest that the older people of tomorrow will be in better health than those of today. Following this logic, in a second scenario we assume that the number of years lived with disability remains stable. In other words, all the years of life expectancy gained are lived in good health. Under this scenario, disability levels will have fallen by around 20\% in each age group by 2030 (Table 2). By comparison with the first, this second scenario reveals the extent to which an improvement in health status is liable to counterbalance the expected increase in the number of persons with disabilities due simply to demographic ageing.

Table 2. Percentage of dependent persons in 2000 and 2030 under the stable health and improved health scenarios by sex, age and marital status (all nine countries)

\begin{tabular}{|c|c|c|c|c|c|c|c|c|c|c|c|}
\hline & \multicolumn{5}{|c|}{ Men } & \multicolumn{5}{|c|}{ Women } & \multirow[b]{2}{*}{ Overal } \\
\hline & Single & Married & Widowed & Divorced & Overall & Single & Married & Widowed & Divorced & Overall & \\
\hline \multicolumn{12}{|c|}{ Age $75-84$} \\
\hline 2000 & 38 & 27 & 31 & 37 & 29 & 40 & 28 & 35 & 39 & 34 & 32 \\
\hline $2030, \mathrm{~s}$ & 38 & 28 & 32 & 38 & 30 & 39 & 29 & 35 & 38 & 33 & 32 \\
\hline 2030, i & 30 & 22 & 25 & 29 & 23 & 32 & 24 & 30 & 32 & 27 & 26 \\
\hline \multicolumn{12}{|l|}{ Age $85+$} \\
\hline 2000 & 51 & 37 & 42 & 49 & 40 & 59 & 47 & 53 & 59 & 53 & 50 \\
\hline $2030, \mathrm{~s}$ & 49 & 37 & 42 & 49 & 39 & 60 & 46 & 52 & 58 & 52 & 47 \\
\hline $2030, \mathrm{i}$ & 39 & 29 & 32 & 38 & 30 & 50 & 39 & 44 & 49 & 43 & 39 \\
\hline \multicolumn{12}{|l|}{ Age 75+ } \\
\hline 2000 & 41 & 28 & 35 & 39 & 30 & 46 & 30 & 42 & 43 & 39 & 36 \\
\hline $2030, \mathrm{~s}$ & 40 & 30 & 36 & 39 & 32 & 44 & 33 & 44 & 42 & 39 & 37 \\
\hline $2030, i$ & 31 & 23 & 28 & 31 & 25 & 37 & 28 & 37 & 36 & 33 & 30 \\
\hline
\end{tabular}

\section{Existence of a surviving child}

Censuses, vital records and national family history surveys provide data on the distribution by age and marital status of the number of children born (Belgium, Czech Republic, Germany, Portugal) or of the number of surviving children (England-Wales, Finland, France, Italy, Netherlands). As we needed to determine how many older adults were liable to lose an only child before 
their death, a series of calculations were made to determine the proportion of children still alive when their parents reach old age. A sex ratio was applied to take account of male/female mortality differentials, and a mean age at birth was estimated (30 for mothers and 32 for fathers) to determine the children's dates of birth so that the appropriate life tables could be used. For Portugal and the Czech Republic, data for men were estimated on the basis of observations available in comparable countries. Last, it was assumed that no children were born after age 45 . Though this assumption is close to reality for women, it leads to a certain over-estimation of the proportion of men who are childless or have no surviving children. Table 3 summarizes the results obtained.

Table 3. Percentage of persons aged 75 and over with no surviving children in 2000 and 2030 by sex and country

\begin{tabular}{|c|c|c|c|c|c|c|c|c|c|c|}
\hline & Belgium & $\begin{array}{c}\text { Czech } \\
\text { Rep. }\end{array}$ & Finland & France & Germany & Italy & $\begin{array}{c}\text { Nether- } \\
\text { lands }\end{array}$ & Portugal & $\begin{array}{c}\text { United } \\
\text { Kingdom }\end{array}$ & Overall \\
\hline $\begin{array}{c}\text { Men } \\
2000\end{array}$ & 18 & 14 & 19 & 23 & 18 & 15 & 11 & 23 & 16 & 18 \\
2030 & 19 & 11 & 26 & 20 & 22 & 16 & 18 & 14 & 20 & 19 \\
\hline $\begin{array}{l}\text { Women } \\
2000\end{array}$ & 19 & 14 & 24 & 24 & 22 & 20 & 21 & 27 & 18 & 21 \\
2030 & 15 & 7 & 20 & 17 & 16 & 14 & 14 & 15 & 14 & 15 \\
\hline
\end{tabular}

At age 75 and over, no link is observed between health status and risk of having no surviving children (Stinner et al., 1990; Henretta et al., 2001). The proportions obtained by age, sex and marital status were thus applied indifferently to persons in both good and poor health. This stage enabled us to break down the future population aged 75 and over by age, sex, marital status, health status and existence of a surviving child.

\section{Future living arrangements}

The last phase involved distributing the various sub-populations obtained by the four most frequent types of elder living arrangements: with a partner, alone, with other persons, in a collective household. France is the only country with data on the distribution of households by all the above-mentioned variables, obtained via the disabilities and dependence survey (Handicaps, Incapacités, Dépendance, HID) conducted in 1999. The national sources from England-Wales (Individual SAR, 2001), Germany (micro-census 1999) and Belgium (census 2001) also detail older people's household structure by respondents' characteristics, with the exception of the "surviving child" variable. For these three countries, it is assumed that the effect of this characteristic on living arrangements is similar to that observed in France. For the other countries (Finland, Netherlands, 
Czech Republic, Italy and Portugal), Europanel data were used for the distribution of living arrangements by age, sex, marital status and health status. The institutionalized population classified by age, sex and marital status was then added on the basis of census data, and it was assumed that health status was similar to that observed in France. Last, the link observed in France between the existence of a child and living arrangements (for a given age, sex, marital status and health status) was also applied to this group of countries.

The distributions by age, sex, marital status, health status and existence of a surviving child obtained in this way for each country in 2000 were maintained constant throughout the period. These projections thus show, in both structural and numerical terms, how population ageing, changes in the sex ratio, marital status, health status and the proportion of persons with no surviving child will impact the living arrangements of dependent older people.

The following four types of living arrangements or households are considered:

- living alone: single-person household;

- living with a partner: with a spouse (married or de facto) and possibly with other persons;

- living with others: includes all forms of coresidence with persons other than a spouse;

- living in a collective household: includes all persons not living in a private household, i.e. at these ages, primarily in institutions. This category is not entirely comparable from one country to another, since persons in sheltered housing are sometimes included here and sometimes counted among private households. This bias could not be eliminated due to lack of data.

\section{Results}

\section{By 2030, dependent elders in Europe will have more potential family carers}

In 2000, a majority of men with disabilities, but only a minority of women, have the potential support of a spouse or child. For most women, the only potential carer is a child, and a larger proportion have no family members to support them. Last, for both sexes, it is rare for a spouse to be the only potential carer ( $7 \%$ of men and $3 \%$ of women).

In the future, family contexts will change for both men and women for two reasons. First, in most countries, fewer people in the generations reaching advanced age will have remained childless (and their children will have survived for longer) and second, marital situations will be different from today. Over the coming decades, we should observe a decline in the number of widows and widowers, and, thanks to a cohort effect, an increase in the proportion of 
Table 4. Percentage distribution of dependent persons aged 75 and above in 2000 and 2030 by family structure (all nine countries)

\begin{tabular}{|l|r|r|r|r|}
\hline & \multicolumn{2}{|c|}{2000} & \multicolumn{2}{c|}{2030} \\
\cline { 2 - 5 } & Men & Women & Men & Women \\
\hline Spouse and surviving child & 53 & 16 & 54 & 30 \\
Spouse, no surviving child & 7 & 3 & 7 & 3 \\
No spouse, surviving child & 29 & 62 & 28 & 54 \\
No spouse and no surviving child & 12 & 19 & 12 & 13 \\
Overall & 100 & 100 & 100 & 100 \\
\hline Source: Felicie, from country data. & \multicolumn{3}{|l}{} \\
\hline
\end{tabular}

divorcees, while the proportion of single persons should remain stable ${ }^{(6)}$. But the intensity of these changes varies by sex and age. The number of widows will fall sharply thanks to lower overall mortality and lower excess male mortality, and this trend will more than offset the growing number of divorcees. Today, $68 \%$ of European women with disabilities aged 75 and over are widows, but by 2030 the proportion may drop to 48\% (respectively $80 \%$ and 63\% among women aged 85 or over) (Table 1). In the future, women throughout Europe, and at all ages, will more frequently have a spouse to support them if they become dependent (Table 4 and Figure 1). In 2000, between 10\% (Czech Republic) and 31\% (Italy) of women aged 75-84 with disabilities are living with a partner. The current maximum will be the minimum in 30 years time (in the Czech Republic, Finland and Portugal), while in Italy the proportion will be $50 \%^{(7)}$. The trend is even more pronounced among women aged 85 and over, for whom the frequency of this living arrangement will increase threefold. By 2030, the women of this age group with disabilities will more often live with a partner than women in the over-75 age group today (respectively, $22 \%$ versus $19 \%$ on average).

Likewise, a smaller proportion of men aged 85 and over will be widowed, so men will more frequently have a spouse to provide care in the event of dependence (48\% in 2030 versus 38\% in 2000, on average). But this is not the case for the 75-84 age group: at these ages, few men are widowed (21\% of dependent men on average) and the decreasing risk of widowhood (the proportion will fall to $13 \%$ by 2030) will not offset the growth in the number of divorced men (which will rise from $3 \%$ to $13 \%$ by 2030). These trends are consistent with those observed in recent decades among the under-75s (Delbès and Gaymu, 2003b). The proportion of men aged 75-84 living with a partner will thus have

(6) Except in Finland, Germany and the Netherlands, where the proportion of single men will practically double, though remaining below $12 \%$.

(7) These proportions should be considered as minima, since the projections do not take account of the probable repartnering of widows, divorcees or single persons. These trends are difficult to quantify since data on unions at these age are scarce. 


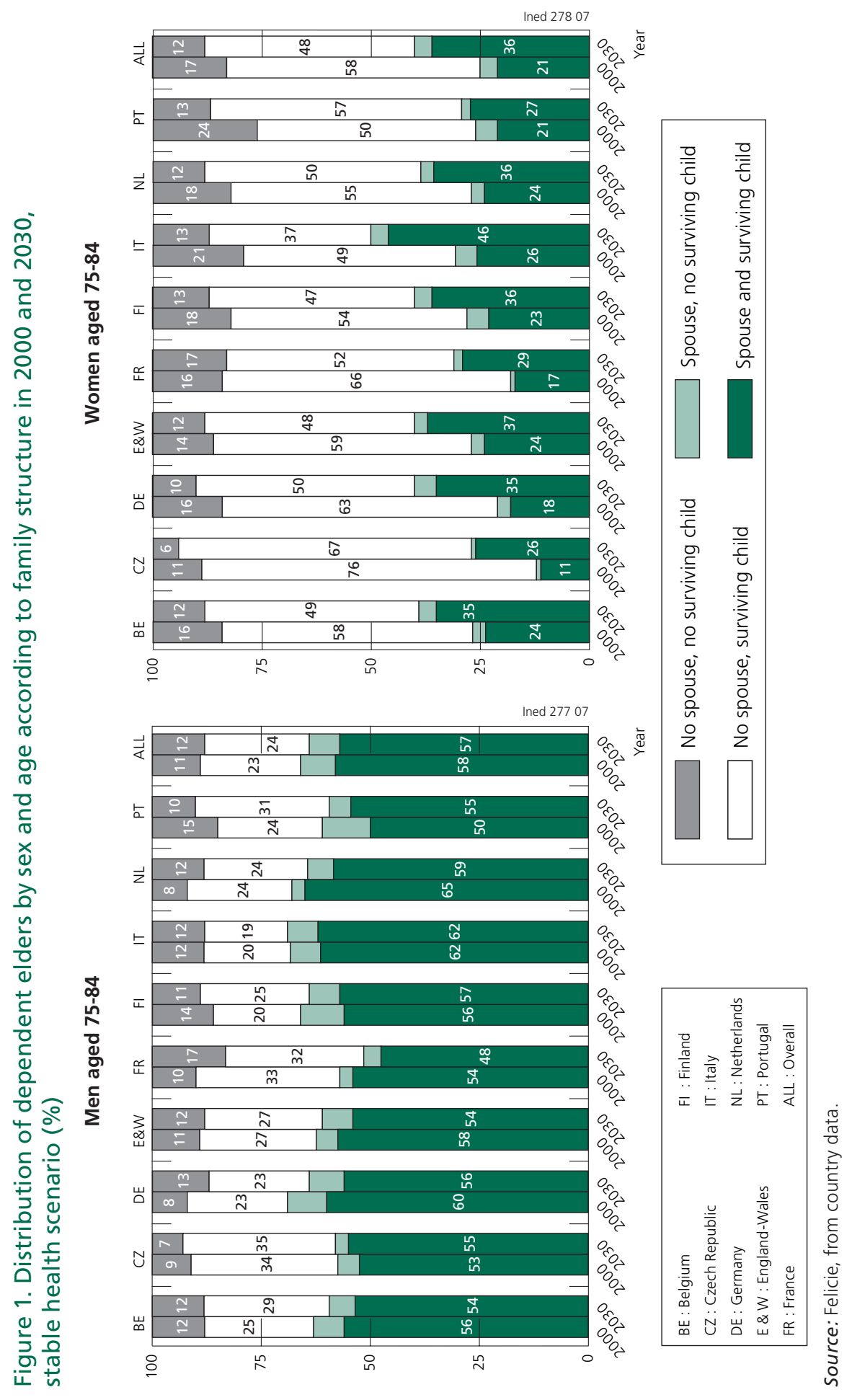




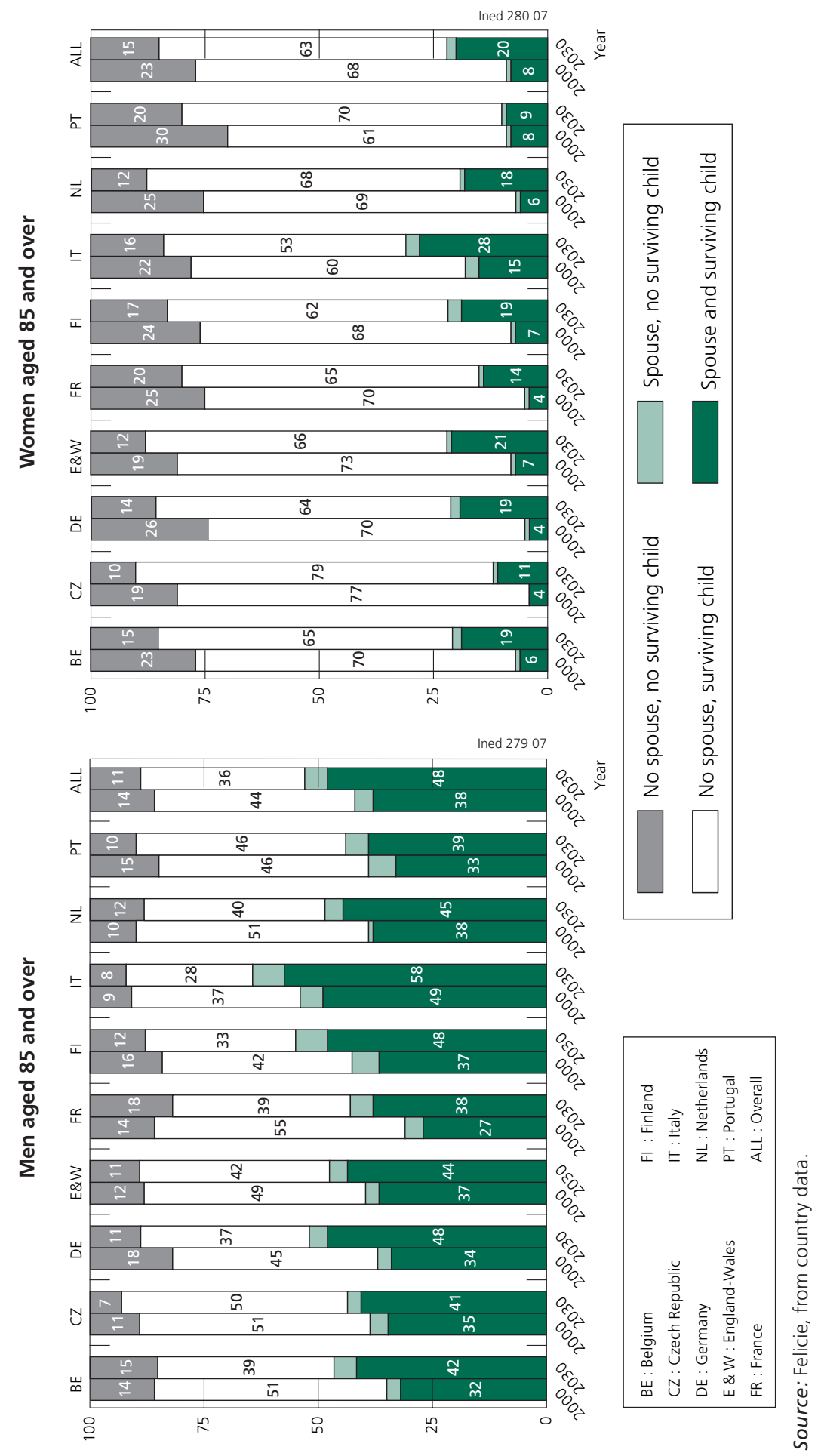


fallen everywhere by 2030, except in the Czech Republic, England-Wales, Italy and Portugal, where it will remain stable (Figure 1).

At these ages, living with a partner depends little on health status: whatever their health status, practically all married persons live with a partner, while the unmarried do so only exceptionally. So an improvement in health will not modify the future proportion of persons living with a partner, and structural changes described here will be valid under both health scenarios.

With regard to children, as the generations born in the interwar period reach age 75 , the proportion of persons with no surviving children will fall steadily everywhere. It will move upwards again at the end of the period for women (as the generations born after World War II reach age 75) while remaining below the proportions observed today. This trend reversal will take place earlier for men, given their higher age at paternity, and will produce a broader range of changes. By 2030, the proportion of childless men will fall in the Czech Republic, France and Portugal, will remain stable in Belgium and Italy and will increase elsewhere, most notably in Finland and the Netherlands (Table 3).

As a consequence, the increased conjugal isolation of men aged 75-84 will more often be associated with childlessness in Finland ${ }^{(8)}$, Germany and the Netherlands. In the other countries, and for men aged over 85 and women at all ages, having no potential family support in the event of dependence will be less frequent. The example of women aged 85 and over, currently most exposed to this risk, clearly illustrates this trend (Figure 1). In 2000, between 19\% (in the Czech Republic) and 30\% (in Portugal) had neither spouse nor child; in 2030, the proportions will range from 10\% (in the Czech Republic) to just 20\% (Finland, Portugal).

With the exception of men aged 75-84, the family environment of older persons with disabilities should improve. They will much more often grow old with a partner, and they will more frequently have at least one surviving child. Yet the degree of availability of family members, their capacity or willingness to look after a dependent spouse, parent or parent-in-law remains an unanswered question. Moreover, a drop in the proportion of persons with no potential family support may well be countered by an increase in the size of the population concerned. An accurate estimate of the numbers of persons in this situation is key to planning the future provision of care and associated services for the dependent elderly population.

\section{The dependent population with no potential family carers may remain stable}

If health status remains unchanged, the dependent population aged 75 and over could have increased by $72 \%$ in 2030 , even doubling, or almost, in

(8) The same is true, but to a lesser extent, for Finnish men aged 85 and over. 
Finland, the Czech Republic and the Netherlands. Elsewhere, growth rates could range from around 60\% (Germany) to 80\% (France). Only in Portugal would growth be less rapid (40\%). To a large extent, this classification reflects disparities in the intensity of the baby boom across Europe.

However, with an improvement in health status, the growth of the elderly dependent population would slow down markedly, with a maximum of $74 \%$ (Netherlands) and a minimum of just 25\% (Portugal), for an average of $41 \%$. Moreover, the above-mentioned changes in the chance of having a spouse and surviving children will affect the numbers of persons opting for each of the various living arrangements. Everywhere, the population of individuals living with a partner will increase faster than that of partnerless individuals, and the population with at least one surviving child will increase faster than that of childless individuals (except in Finland and the Netherlands). For all countries, and under the stable health scenario, growth rates up to 2030 range between $145 \%$ for the population with both a partner and surviving child, and $25 \%$ for the childless, partnerless, population. They reach $96 \%$ for the population with a partner but no surviving child, and $47 \%$ for the population in the opposition situation.

In other words, the most vulnerable population, with no family carers, will increase much more slowly than the other dependent population categories, and the implications of an improvement in health status are illustrated very clearly here. Under this scenario, the population with the greatest need of professional services, including institutional care, will decrease or remain practically stable in all countries. It will grow by only around 10\% in France and Belgium, and 20\% in the Netherlands. Finland remains an exception, with growth of $73 \%$.

\section{The population of dependent persons with both a spouse and surviving child will post the largest increase}

In principle, a dependent person living with a partner or having a surviving child is less vulnerable, though the spouse's health may be poor and the child or children may be unavailable. In other words, these people may be in a precarious family situation and have a strong need of professional assistance.

The population of older adults living with a partner but with no surviving children will increase rapidly. In all countries - apart from the Czech Republic, France and Portugal - growth rates are higher, or even much higher than those of dependent persons in general. But only a minority of the older population will be concerned: in 2030, the highest level (8\%) will be reached by Germans aged $75-84$.

However, having neither spouse nor surviving children to provide care in the event of dependence is a more common situation. It is even the typical profile of older women with disabilities. This population is set to increase 


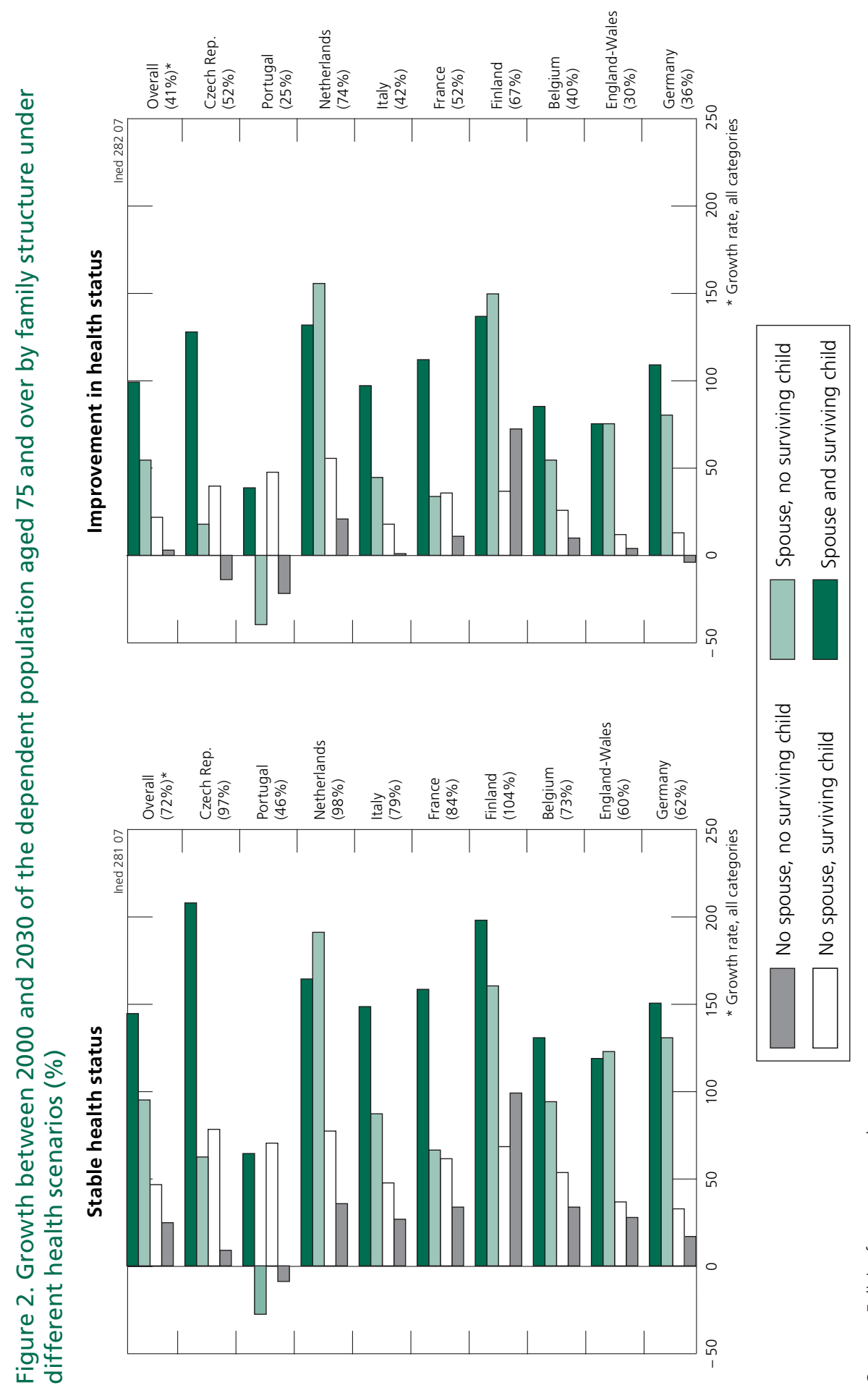


steadily everywhere, though more slowly than the dependent population as a whole (Figure 2). If health status remains stable, the increase will range between 35\% in Germany and England-Wales, and almost 80\% in the Czech Republic and the Netherlands. If health improves, growth will be much slower, ranging from slightly over $10 \%$ to under $60 \%$. Last, by 2030 , the largest increase in the population with disabilities will be among persons with both a partner and surviving child. On average, this category will grow twice as fast as the overall population with disabilities. If health status remains stable, it will increase by 65\% in Portugal, it will more than double in England-Wales, it will be multiplied by 2.5 in the other countries and even triple in Finland and the Czech Republic. Under the improved health scenario, growth rates would range from 39\% (Portugal) to $138 \%$ (Finland).

These results show that in the future, a new balance between professional and family care will need to be found. Whatever the future health status, the populations requiring professional care will grow much more slowly than those with potential sources of family support. This change in the internal composition of the dependent population is largely predetermined by the demographic history of the cohorts concerned. On this point, the main uncertainty concerns trends in marital structures. Yet we know that the projected trends are based on robust assumptions (Kalogirou and Murphy, 2006). In fact, they depend mainly on the current proportion of married persons and on mortality trends, with changes in marriage rates, divorce rates and migration having only marginal effects. Various mortality assumptions were tested successively, but their effect on the estimates of matrimonial structure are very limited.

The results illustrated in Figure 2 also show the extent to which an improvement in health status could change the amplitude of growth in need of assistance. Not only would the growth rate of the population with disabilities be practically halved (from $72 \%$ to $41 \%$ ), but the population with no family support would remain stable in practically all countries, decreasing even in the Czech Republic, Germany and Portugal.

\section{The dependent population will grow older and potential carers will more often be husbands}

A breakdown of these trends by sex and age sheds further light on future structural changes in the population with disabilities (see the improved health scenario in Figure 3, which illustrates the minimum expected changes). The number of men aged 85 and over will double, while those aged 75-84 will increase by only $55 \%$ ( $43 \%$ and $22 \%$, respectively, among women). This ageing process will certainly generate increased demand for professional care, since disabilities become more severe with advancing age (Colin and Coutton, 2000), and potential family carers, themselves growing old, are less able to shoulder the burden. 


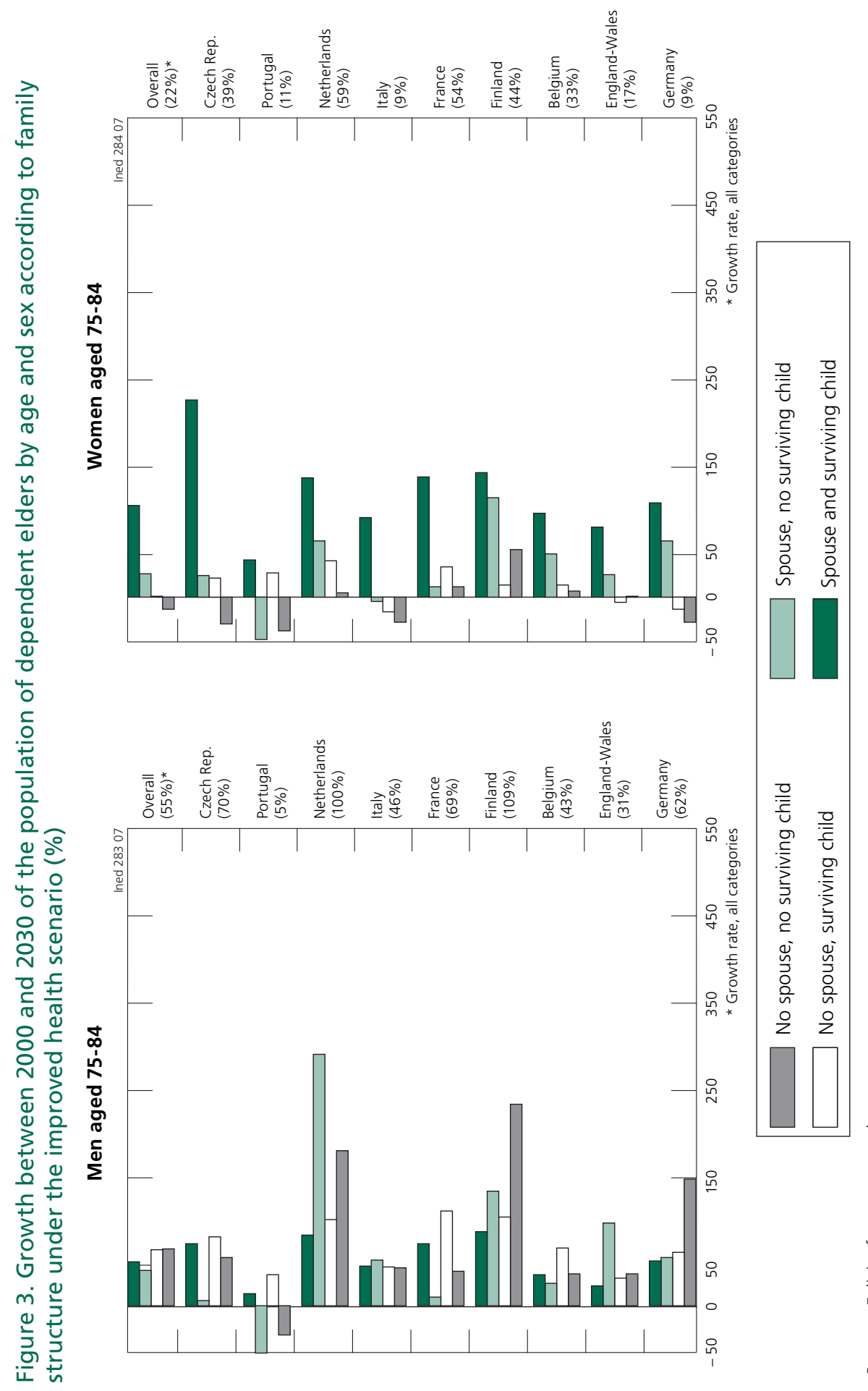

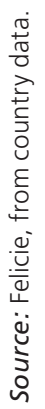




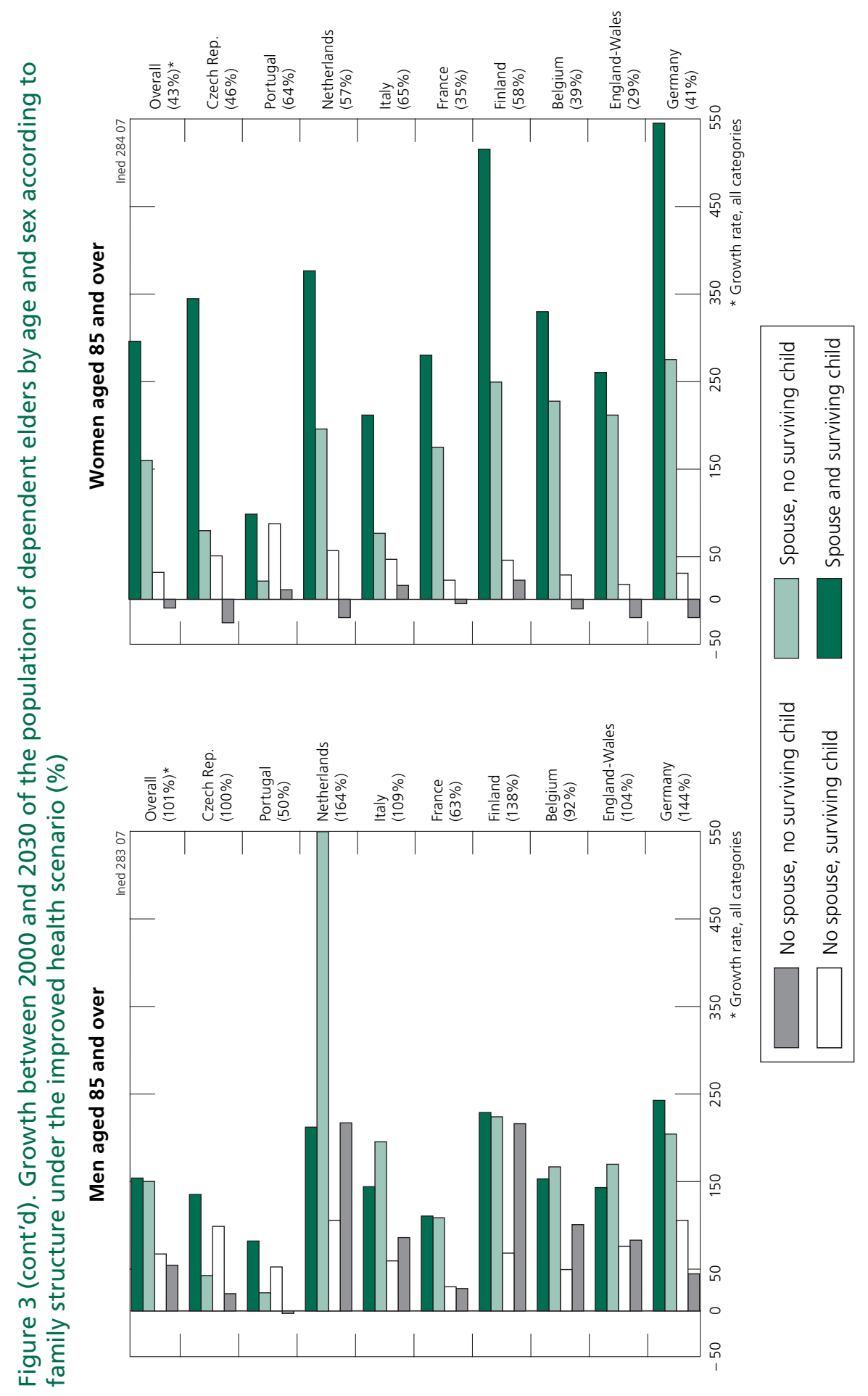

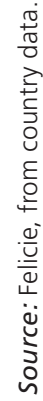


Moreover, compared with the male population, the number of women aged 85 and over with a partner and surviving child will grow more quickly. Their number will be multiplied by 2.5 , at the very least ${ }^{(9)}$, in England-Wales, France and Italy, by three in Belgium, the Czech Republic and the Netherlands, and by more than five in Germany and Finland. Among men, growth rates are, on average, only half this level, and the proportion of widowers will fall more slowly.

In view of these changes, the structure of the population aged 85 and over with disabilities will have changed radically by 2030 (Figure 4). At present, across all nine countries, $53 \%$ of this population is made up of women with no partner and whose only potential carers are their children, and a further $18 \%$ have no available family support. By 2030, these proportions will have fallen to $45 \%$ and $11 \%$ respectively. But the downside of this reduction in female conjugal isolation will be an increase in the proportion of men facing the problem of a dependent partner. Today, among the oldest-old, the wife is the potential carer in $9 \%$ of cases, and the husband in $7 \%$; by 2030, these percentages will reach $15 \%$ and $16 \%{ }^{(10)}$, respectively. But today, men find it more difficult to cope with a dependent spouse than do women. They more often bring in professional help (Martel and Légaré, 2001) or place their spouse in an institution (Delbès and Gaymu, 2006).

Likewise, a growing proportion of women aged 85 and over will have a dependent husband. In 2000, 16\% of dependent persons lived with a partner, but by 2030 this percentage will have practically doubled to $31 \%{ }^{(11)}$. And it is estimated $^{(12)}$ that half of these persons today have a spouse with health problems. In the future, the dependent population will thus more often comprise couples where both partners have disabilities.

The additional population with disabilities in 2030 will mainly comprise persons with potential family carers. However, the internal ageing of this population, the growing number of husbands providing care and the more frequent survival of couples comprising two dependent partners will generate increased demand for professional care. Even if future dependent persons more often have a partner, it is nonetheless true that in 2030, in all countries, around two in three dependent women and two in five dependent men aged 75 and over will not. Various options are open to these persons: they can continue to live alone in their own home, they can go and live with others (a living arrangement which, for non-married persons, may have been chosen at a much earlier date), or move into an institution.

(9) i.e. if health status improves.

(10) This observation is true for all countries, and for Germany, Finland and Belgium especially.

(11) The same trends are observed in the dependent population aged 75-84: on average, in 2000, the wife was a potential carer in $22 \%$ of cases, and the husband in $17 \%$ of cases. For both, the percentage will be $25 \%$ in 2030 .

(12) Based on 2001 Belgian census data. 
Figure 4. Structure of the dependent population aged 85 and over in 2000 and 2030 by sex and family structure (\%)

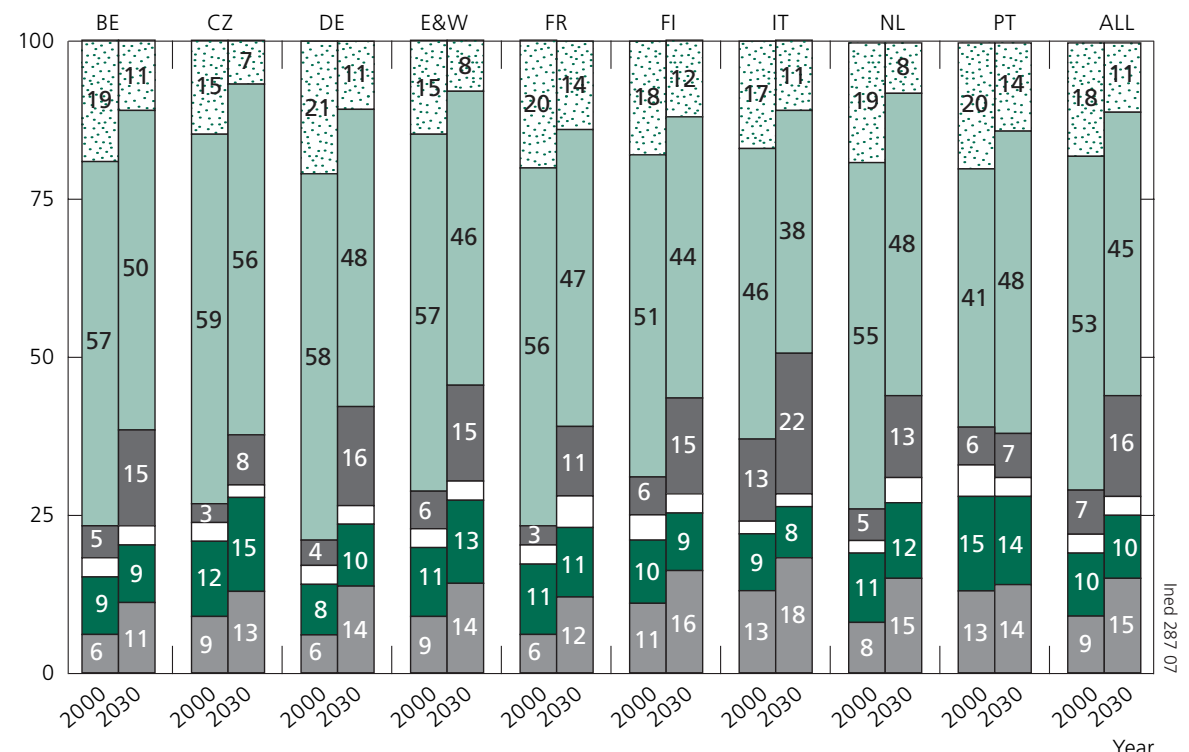

\begin{tabular}{|llll}
\hline BE : Belgium & FI : Finland & IT : Italy & ALL : Overall \\
CZ: Czech Republic & E \& W : England-Wales & NL: Netherlands & \\
DE : Germany & FR : France & PT : Portugal &
\end{tabular}

\begin{tabular}{|l|l|}
\hline Men with partner & Women with partner \\
\hline Men without partner or children & \\
Partnerless men & Women without \\
parther or children \\
with surviving child & $\begin{array}{l}\text { Partnerless women } \\
\text { with surviving child }\end{array}$ \\
\hline
\end{tabular}

Source: Felicie, from country data.

Note that these suppositions are based on the assumption that older people's behaviour patterns will remain unchanged. The results presented in this article aim to show how changes in old people's sociodemographic characteristics generally determined by their history - will transform their living arrangements. What actually happens to older people will, of course, be influenced by a range of other factors (notably, future care provision policies) which are difficult to predict.

\section{Increased demand for home care services and places in institutions}

Two of the factors taken into account in these projections - being childless and being single - have a crucial impact on the living arrangements of persons 
with disabilities who do not live with a partner. Both reduce residential autonomy and increase the risk of institutionalization ${ }^{(13)}$.

The proportion of men and women with no surviving children will decrease in all countries, with the exception of Dutch and Finnish men and, to a lesser extent, German men aged 75-84. The same applies for the future proportions of single persons. As a consequence, in these three countries, partnerless men will more often live alone, with no support from children (12\% in 2030 compared with 7\% in 2000 among Finnish men aged 85 and over, for example), and in institutions. Elsewhere, and among women in the nine countries studied, the more frequent existence of a surviving child will only produce very marginal changes in the distribution of living arrangements among partnerless people (Table 5). Only for Portuguese women, among whom the proportion of permanently childless will drop most sharply, will the change be slightly more pronounced (the percentage of women living alone and having a surviving child will rise from $19 \%$ in 2000 to $24 \%$ in 2030 ).

Table 5. Distribution of the dependent population not living with a partner by living arrangement in 2000 and 2030, by age and sex (\%)

\begin{tabular}{|c|c|c|c|c|c|}
\hline & $\begin{array}{l}\text { Lives alone, } \\
\text { surviving } \\
\text { child }\end{array}$ & $\begin{array}{l}\text { Lives alone, } \\
\text { no surviving } \\
\text { child }\end{array}$ & $\begin{array}{l}\text { Lives } \\
\text { with other } \\
\text { people }\end{array}$ & $\begin{array}{l}\text { Institution- } \\
\text { alized }\end{array}$ & Overall \\
\hline \multicolumn{6}{|c|}{ Men aged 75-84 } \\
\hline 2000 & 30 & 14 & 31 & 25 & 100 \\
\hline 2030 & 32 & 14 & 30 & 24 & 100 \\
\hline \multicolumn{6}{|c|}{ Women aged 75-84 } \\
\hline 2000 & 41 & 11 & 29 & 19 & 100 \\
\hline 2030 & 43 & 9 & 29 & 19 & 100 \\
\hline \multicolumn{6}{|c|}{ Men aged $85+$} \\
\hline 2000 & 27 & 7 & 27 & 39 & 100 \\
\hline 2030 & 26 & 7 & 27 & 40 & 100 \\
\hline \multicolumn{6}{|c|}{ Women aged $85+$} \\
\hline 2000 & 29 & 8 & 26 & 37 & 100 \\
\hline 2030 & 31 & 7 & 26 & 36 & 100 \\
\hline
\end{tabular}

However, we noted earlier that the partnerless population will increase (by $42 \%$ on average under a stable health scenario, and by $17 \%$ under an improved health scenario), though more slowly than the dependent population

(13) For example, in 2000, for all countries, $40 \%$ of single men aged 75 and over with disabilities lived in an institution, compared with only $23 \%$ of widowers. But for widowers, having a child makes a significant difference. Only $21 \%$ of widowers with children live in an institution, compared with $36 \%$ of those who are childless. 
as a whole (respectively $72 \%$ and $41 \%$ ). This trend will generate additional demand for home care services and for places in institutions.

\section{Contrasting trends for men and women}

Under both stable and improved health scenarios, apart from a few rare exceptions, the numbers of persons concerned by all types of living arrangement will increase up to 2030. The intensity of changes follows a remarkably consistent pattern in all categories (Figure 5). The only population that grows more slowly is the category of persons living alone with no surviving children (except in Finland), who are the most likely to call upon professional assistance.

But the changes affect men and women very differently (Table 6). Among women aged 75 and over, and under a stable health scenario, the population living alone with no surviving children grows by only $4 \%$ on average, compared with around $30 \%$ for the other categories. It even decreases in Germany, Portugal and the Czech Republic, and likewise in all countries except Finland, France and Belgium under an improved health scenario. The equivalent population among men will double on average, and disparities in the degree of variation between countries are wider: this population declines in Portugal, increases more markedly than the other categories in Germany $(+204 \%)$, the Netherlands (+223\%) and Finland (+304\%), and less markedly in the other countries. The same hierarchy is also observed for the improved health scenario, though if the health of older people improves, rates of growth will necessarily be slower.

The pattern of increase in the population living alone and having a surviving child also varies by sex. In all countries, it will rise by $33 \%$ among women, but here again will double among men, although, as before, variations between countries are very large. The future increase in the proportion of men in this category will certainly raise demand for professional assistance, since few divorced men can count on the support of their children. Indeed, many studies have shown that unlike their female counterparts, divorced men will receive little assistance from their children (Cooney and Uhlenberg, 1990; AttiasDonfut, 1995). Yet the number of male divorcees will increase rapidly everywhere: under the improved health scenario, their numbers will be multiplied by at least five ${ }^{(14)}$.

Last, generally speaking, the population living with persons other than a spouse or in an institution will increase in a similar manner. Under a stable health scenario, demand for institutional places will increase by around 70$80 \%$ in the Czech Republic, Finland and the Netherlands, 40-50\% in Belgium, France and Italy, and 35-40\% in Germany, England-Wales and Portugal

(14) Under the improved health scenario, for a base 100 in year 2000, the number of dependent divorced men living alone and having a surviving child will reach an index of 658 in Belgium, 638 in the Czech Republic, 535 in England-Wales, 633 in Finland, 655 in France, 683 in Germany, 1543 in Italy, 494 in the Netherlands and 759 in Portugal. 


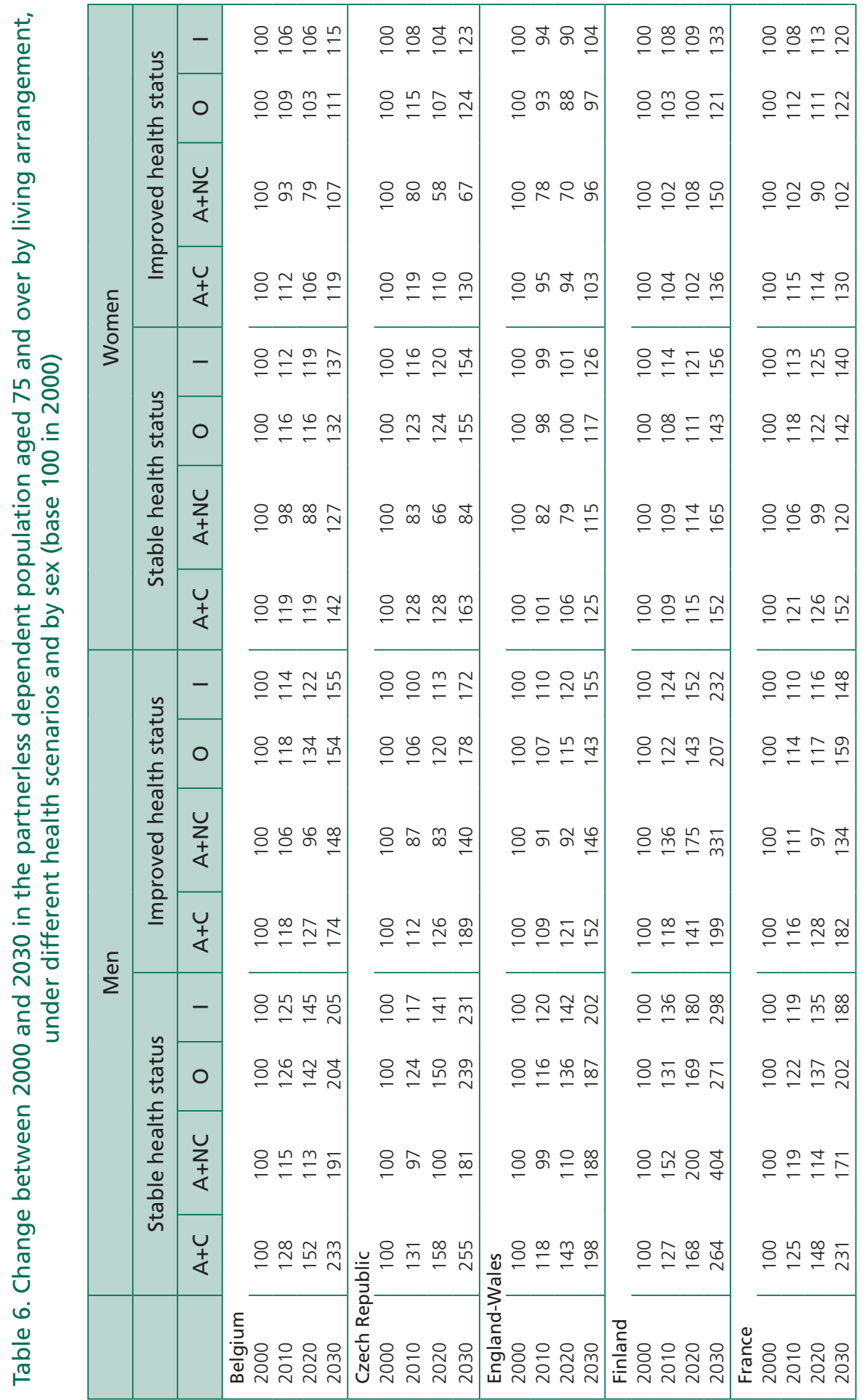




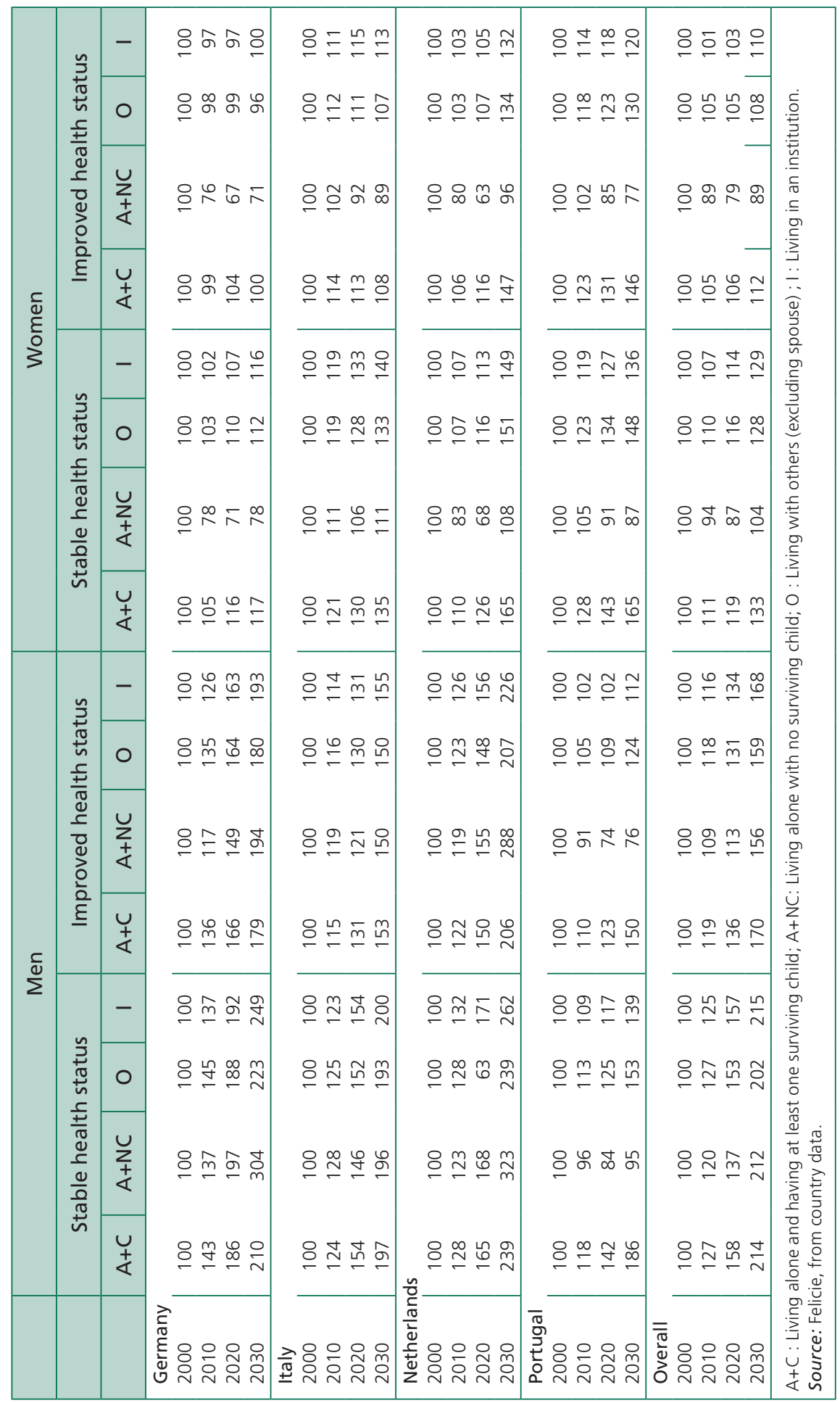




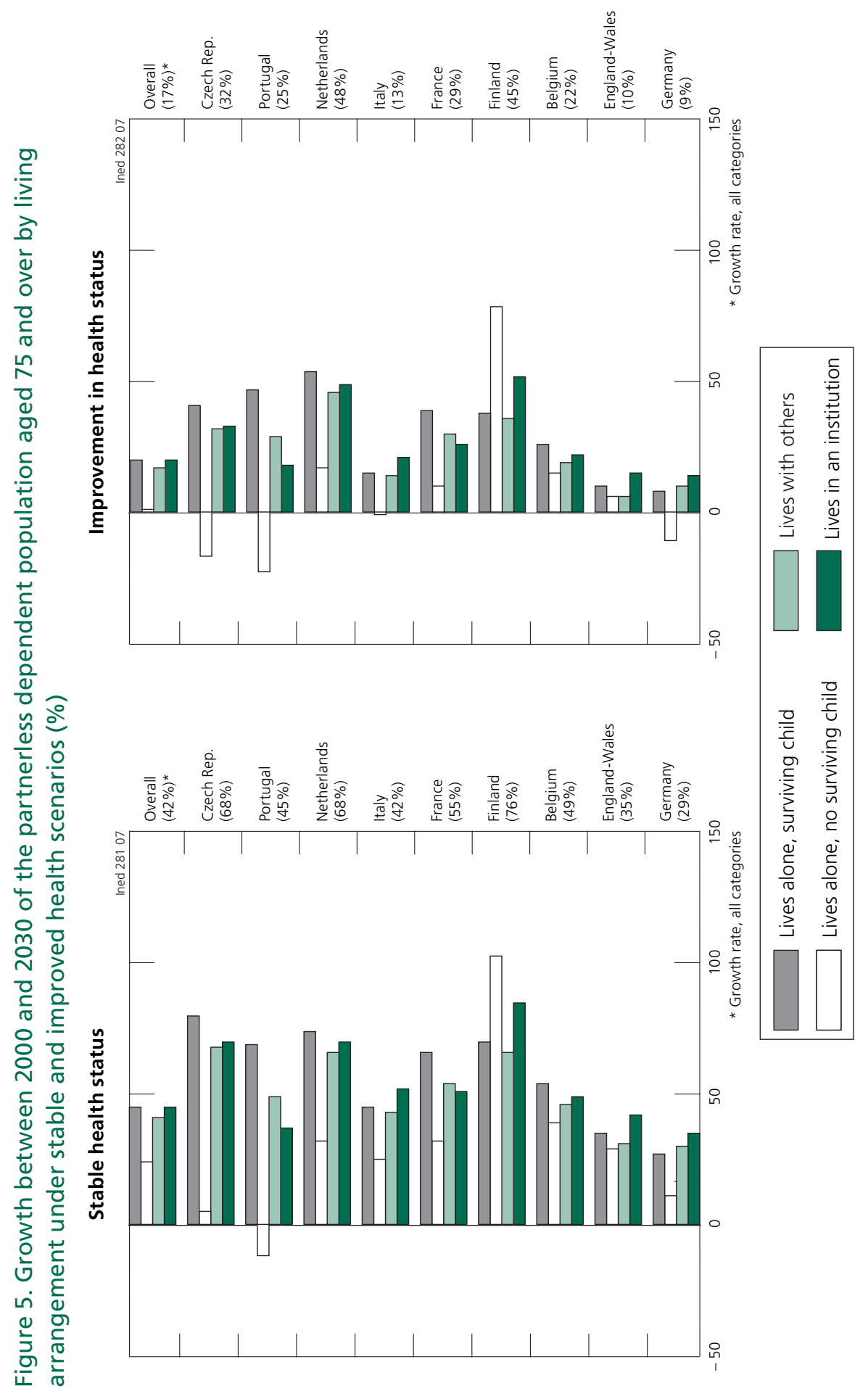

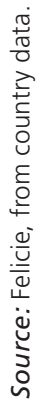


(Figure 5). This country classification roughly mirrors the contrasts observed in the overall growth in the dependent population. Here, the impact of improvements in health status will be decisive: under this scenario, the abovementioned growth in the population living in an institution is divided by 2 or even 2.5 in all countries ${ }^{(15)}$.

\section{Accelerated change from 2020}

Table 6 gives a further indication of the intensity of change over time. Thanks to the mortality decline, more people will reach age 75 and survive for longer beyond that age, a phenomenon compounded by the arrival of the first baby-boom generations at this age threshold from 2020. The increase will thus accelerate from this date in most countries, the sole exceptions being Germany, Italy and Portugal. In these countries, less affected by the baby boom, the increase remains steady over the entire period.

Apart from these few exceptions, most of the expected growth will not occur until after 2020, and the pace of change will accelerate in all cases (Table 6). The growth in male demand for institutional places provides a very explicit illustration of this: with the exception of Portugal, this population is expected $^{(16)}$ to double at least (Belgium) or triple at most (Finland), though the level of growth is practically the same between 2020 and 2030 as over the twenty preceding years. The example of men living alone with no surviving children is equally striking. This population, whose need of professional assistance is high, should double on average by 2030, though will remain practically stable over the next twenty years in Belgium, the Czech Republic England-Wales and France.

\section{Conclusion}

Between now and 2030, as mortality declines and the baby-boom cohorts reach old age, the dependent population aged 75 and over in Europe is expected to increase by around $70 \%$ on average if current levels of disability by age and marital status remain unchanged. Though there is much uncertainty about future health trends, the hypothesis of health improvement considered here shows the decisive extent to which this factor could affect needs of assistance over coming years. If, in the future, all the years of life expectancy gained were years spent in good health, the number of older Europeans with disabilities would increase by no more than $40 \%$. Moreover, beyond these general developments, the family context of dependence will change in many ways as a new set of generations reach old age. Over the next 25 years, whatever the overall health trends, the supply of potential family carers, i.e. partners and

(15) Except for Finland and the Netherlands, where it is divided by around 1.5.

(16) Under a stable health scenario. 
offspring, will increase, and populations with the greatest need of professional assistance - persons living alone with no available family members or those liable to enter an institution - will grow more slowly than the dependent population in general. However, the ageing of this population, the growing number of elderly men with a dependent spouse and the greater longevity of couples in which both members have disabilities, all point to growth in demand for professional assistance in years to come. In the future, even more so than today, support for carers must become a key component of care provision for the dependent elderly.

For example, one of the main findings of these projections is a reduction in the number of older women living alone. However, this trend will not be associated with a more positive experience of dependence unless the partners of these women are able to address their needs effectively. The same reservations apply with respect to children. Though more older people in the future will have surviving children, these children may not be available or willing to provide support.

Indeed, a crucial limitation of this research is the fact that it does not take account of possible changes in behaviour or in care provision policies. Such changes might produce far more radical transformations in the living arrangements of partnerless older people's than those predicted here, but are difficult to foresee.

For example, although daughters are much more frequently called upon than sons to look after their elderly parents, women's increased labour force participation will reduce their availability for this task. Recent research indicates that women are able to reconcile these dual obligations, but sometimes at the expense of their professional career. When care demands are high, their working hours are substantially reduced (Ettner, 1995; Spiess and Schneider, 2003). Nonetheless, the women of tomorrow, living in more egalitarian unions and with an identity outside the family, in the professional sphere especially, may be unwilling to accept the constraints imposed by dependent parents and/or parents-in-law. Indeed, many studies show that they do so at the expense of their health. The stress and strain of caring for dependent parents increase the risk of mental health problems, depression in particular (Schulz et al., 1995). Moreover, some suggest that the older people of tomorrow might be less willing to be seen as a potential burden on their family and to rely on their daughters as carers. Today, in countries where professional services are widely available, older people show a strong preference for non-family support, especially when they require personal or long-term care. Elsewhere, it would appear that the wishes of older people have not been satisfied, and in all countries, most of them agree that in future, the needs of dependent elders should be met primarily by professional carers (Daatland and Herlofson, 2003).

But this raises the question of their ability to pay for these services and, consequently, to continue living in their own homes. Over recent decades, 
partnerless older persons throughout Europe have opted increasingly to stay in their own home rather than cohabit with other family members. The different generations today more strongly favour residential independence, a preference now more often realized, thanks to the improved economic situation of older persons (Michael et al., 1980; Mickus et al., 1997; McGarry and Schoeni, 2000). Whether or not this trend continues will depend upon the future purchasing power of older persons: if it remains stable or increases, the population living alone could increase much faster than predicted in our projections. Of course, certain structural changes in the older population (increased female labour force participation, higher qualifications) should raise older people's future living standards. However, everywhere in Europe, the future financing of pensions is uncertain, and hence the future ability of older people to afford the professional assistance they may need. Moreover, faced with the escalating costs of social protection, collective solidarity may be undermined. Falling incomes and/or the withdrawal of state support for home care would, ipso facto, place additional pressure on families which already represent the mainstay of support for the most vulnerable (Mestheneos and Triantafillou, 2005).

The challenges facing the different countries of Europe will vary in scale. The diversity of past demographic behaviours is shaping the future pattern of growth in the dependent population. It may increase by only $50-60 \%$ in Germany, England-Wales and Portugal, but double in Finland, the Netherlands and the Czech Republic if health status remains unchanged. If health improves, the increase will range from 25\% (Portugal), to 74\% (Netherlands), with the other countries holding an intermediate position. Everywhere, the population of partnerless elders dependent on non-family support will grow more slowly, with generally similar country rankings. The fate of these individuals coresidence with family members or institutionalization - will depend upon the future attitudes of families and the future government policies in each country. Today, the countries of Europe are responding in very different ways: those in the south favour family solidarity via intergenerational coresidence, while those of the north favour collective solidarity via institutional care. These two forms of solidarity are nonetheless indissociable and interdependent. Beyond the problem of cost, the limited availability of care infrastructures for older people in southern Europe is linked to a strong tradition of family solidarity (Reher, 1998). But one might also argue that the high frequency of intergenerational coresidence in the region is also partly linked to the absence of alternative solutions. Likewise, policies to reduce the number of older adults in institutions, as implemented in certain countries such as the Netherlands (Jacobzone et al., 2000), may ultimately give rise to new forms of family solidarity. The map of older people's living arrangements in Europe may be completely redrawn. 
Acknowledgements. We are extremely grateful to the European Commission which funded the Felicie project (contract no. QLK6-CT 2002-02310) and to our colleagues in the various national teams who supplied the data and who helped to produce these projections: G. Doblhammer and W. Apt (MPIDF) for Germany; M. Poulain and L. Dal (GEDAP) for Belgium; P. Martikainen and E. Nihtilä (University ofHelsinki) for Finland; C. Delbès, A. Désesquelles, P. Festy, S. Pennec and S. Springer (Ined) for France; G. De Santis, C. Seghieri and M. L. Tanturri (University of Florence) for Italy; H. Cruisen, E. van Imhoff and L. van Wissem (NIDI) for the Netherlands; A. Fernandes, T. Veiga and F. de Castro Henriques (University ofLisbon) for Portugal; J. Rychtarikova (Charles University, Prague) for the Czech Republic; E. Grundy, C. Tomassini (LSHTM) and S. Kalogirou, M. Murphy (LSE) for the United Kingdom. 


\section{REFERENCES}

ANGEL R.J., Himes C.L., 1992, "Minority group status, health transitions, and community living arrangements among the elderly", Research on Ageing, vol. 14, pp. 496-521.

Arber S., Gilber G. N., EVANDrou M., 1988, "Gender, household composition and receipt of domiciliary services by elderly disabled people", Journal of Social Policy, 17, pp. 153-175.

AtTias-Donfut C. (ed.), 1995, Les solidarités entre les générations, Paris, Nathan, coll. Essais et Recherches, $352 \mathrm{p}$.

BREUIL-GENIER P., 1998, "La dépendance des personnes âgées : recours aux proches et aux aides professionnelles", in France: Portrait social, Insee, pp. 91-107.

CARRIÈRE Y., PELlETIER L., 1995, "Factors underlying the institutionalization of elderly persons in Canada", Journal of Gerontology: Social Sciences, 50B (3), pp. 164-172.

CHAPPELL N.L., 1991, "Living arrangements and sources of care giving", Journal of Gerontology, 46, pp. S1-8,

Colin C., COUTTON V., 2000, "Le nombre de personnes âgées dépendantes", Études et Résultats, 94, $7 \mathrm{p}$.

Comas-Herrera A., Wittenberg R., Costa-Font J., Gori C., Di Maio A., Patxot C., PiCKARD L., POZZI A., ROTHGANG H., 2006, "Future long-term care expenditure in Germany, Spain, Italy and the United Kingdom", Ageing and Society, 26, pp. 285-302.

COONEY T., UHLENBERG P., 1990, "The role of divorce in men's relations with adult children after mid-life", Journal of Marriage and the Family, 52, pp. 677-688.

DAATLAND S.O., HERLOFSON K., 2003, “'Lost solidarity' or 'changed solidarity': a comparative European view of normative family solidarity", Ageing and Society, 23, pp. 537-560.

De Jong Gierveld J., Van Tilburg T., Lecchini L., 1997, "Socio-economic resources, household composition and social network as determinants of well-being among Dutch and Tuscan older adults", Genus, vol. III, 3-4, pp. 75-100.

DELBĖS C., GAYMU J., 2003a, La retraite, quinze ans après, Les Cahiers de l'Ined, 154, 223 p.

Delbès C., GAYMU J., 2003b, "More unions surviving after 60?", Population and Sociéties, 389, $4 \mathrm{p}$.

Delbès C., GAYMU J., 2006, "Women grow old alone, but men grow old with a partner. A European overview", Population and Sociéties, 419, 4 p.

DÉSESQUELLES A., BROUARD N., 2003, The family networks of people aged 60 and living at home or in an institution, Population, English Edition, 58(2), pp. 181-206.

DOLINSKY A. L., ROSENWAIKE I., 1988, "The role of demographic factors in the institutionalization of the elderly", Research on Aging, 10 (2), pp. 235-257.

Duée M., Rebillard C., PenneC S., 2005, "Les personnes dépendantes en France : évolution et prise en charge", paper presented at the IUSSP 25th International Population Conference, Tours, France 18-23 July.

ETTNER S.L., 1995, "The impact of "parent care" on female labor supply decisions", Demography, 32(1), pp. 63-80.

Gaymu J., Delbès C., Springer S., Binet A., DéSesquelles A., Kalogirou S., Ziegler U., 2006, "Determinants of the living arrangements of older people in Europe", European Journal of Population, 22(3), pp. 241-262.

GLASER K., MURPHY M., GRUNDY E., 1997, "Limiting long-term illness and household structure among people aged 45 and over, Great Britain 1991", Ageing and Society, 17, pp. 3-19.

GLASER K., TOMASSINI C., GRUNDY E., 2004, "Revisiting convergence and divergence: support for older people in Europe", European Journal of Ageing, 1, pp. 64-75.

GRUNDY E., GLASER K., 1997, "Trends in, and transitions to, institutional residence among older people in England and Wales 1971-1991", Journal of Epidemiology and Community Health, 51, pp. 531-540.

GRUNDY E., 2006, "Ageing and vulnerable people: European perspectives", Ageing and Society, 26, p. 105-134. 
Henretta J. C., Grundy E., HARriS S., 2001, "Socioeconomic differences in having living parents and children: a US-British comparison of middle-aged women", Journal of Marriage and Family, 63, pp. 852-867.

IACOVOU M., 2000, "Health, wealth and progeny: explaining the living arrangements of older European women”, available online at <http://www.iser.essex.ac.uk/pubs/workpaps/pdf/ 2000-08.pdf>

Jacobzone S., CAmbois E., Robine J.-M., 2000, "Is the health of older persons in OECD countries improving fast enough to compensate for population ageing?", OECD Economic Studies, 30,pp. 149-190.

Kalogirou S., Murphy M., 2006, "Marital status of people aged 75 and over in nine EU countries in the period 2000-2030", European Journal of Ageing, 3, pp. 74-81.

KEEFE J., LÉGARÉ J., CARRIÈRE Y., 2005, "Developing new strategies to support future caregivers of the aged in Canada : projections of need and their policy implications", paper presented at the IUSSP 25th International Population Conference, Tours, France 18-23 July.

LÉGARÉ J., MARTEL L., 2003, "Living arrangements of older persons in the early ninety's: an international comparison", Genus, 59 (1), pp. 85-103.

MARTEL L., LÉGARÉ J., 2001, "Avec ou sans famille proche à la vieillesse : une description du réseau de soutien informel des personnes âgées selon la présence du conjoint et des enfants", Cahiers québécois de démographie, 30(1), pp. 89-114.

MCGARRY K., SCHOENI R.F., 2000, "Social security, economic growth, and the rise of the elderly widow's independence in the twentieth century", Demography, 37 (2), pp. 221-236.

Mestheneos E., Triantafillou J., 2005, Supporting Family Carers of Older People in Europe. The Pan-European Background Report, Lit Verlag, 160 p.

MichaEL R., FuCHS V., SCOTT S., 1980, "Changes in the propensity to live alone: 1950-1976", Demography, 17, pp. 39-56.

MiCKUS M., STOMMEL M., GIVEN C.W., 1997, "Changes in living arrangements of functionally dependent older adults and their adult children", Journal of Ageing and Health, 9(1), pp. 126-143.

MURPHY M., GRUNDY E., 1994, "Co-residence of generations and household structure in Britain: Aspects of change in the 1980s" in H. Becker and P. L. J. Hermkens (eds.), Solidarity of Generations: Demographic, Economic and Social Change and its Consequences, Amsterdam, Thesis Publishers, pp. 551-582.

PALlONi A., 2001, "Living arrangements of older persons", in Living Arrangements of Older Persons: Critical Issues and Policy Responses, Population Bulletin of the United Nations, Special issue 42/43, New York, United Nations, pp. 54-110.

PAMPEL F.C., 1992, "Trends in living alone among the elderly in Europe" in A. Rogers (ed.), Elderly Migration and Population Redistribution, London, Belhaven Press, pp. 97-117.

Pickard L., Wittenberg R., Comas-Herrera A., Davies B., Darton R., 2000, "Relying on informal care in the new century? Informal care for elderly people in England to 2031", Ageing and Society, 20, pp. 745-772.

REHER D.S., 1998, "Family ties in Western Europe: Persistent contrasts", Population and Development Review, 2, pp. 203-234.

RICCI M., 1991, "Residential care for the elderly in Italy: Recent trends and regional differences", communication présentée à la European Population Conference, session "Living arrangements of the elderly", Paris, 21-25 octobre.

Robine J.-M., ROMieU I., MiChel J.-P., 2003, "Trends in health expectancies" in Robine J.-M., Jagger C., Mathers C. D., Crimmins E. M., Suzman R. M. (eds.), Determining Health Expectancies, Chichester, West Sussex, Wiley, pp. 75-101.

RUGGLES S., 2001, "Living arrangements and well-being of older persons in the past", in Living Arrangements of Older Persons: Critical Issues and Policy Responses, Population Bulletin of the United Nations, Special issue 42/43, New York, United Nations, pp. 111-161.

SCHulz R., O’Brien A. T., BOOKWAla J., Fleissner K., 1995, "Psychiatric and physical morbidity effects of dementia caregiving: Prevalence, correlates and causes", The Gerontologist, 35(6), pp. 771-791. 
Soldo B. J., Wolf D. A., AGREE E. M., 1990, "Family, households, and care arrangements of frail older women: A structural analysis", Journal of Gerontology, 45, pp. S238-249.

SPIESS C. K., SCHNEIDER A.U., 2003, "Interactions between care-giving and paid work hours among European midlife women, 1994 to 1996", Ageing and Society, 23, pp. 41-68.

STINNER W. F., BYUn Y., PAitA L., 1990, "Disability and living arrangements among elderly American men", Research on Aging, 12, pp. 339-363.

Tomassini C., Glaser K., Wolf D. A., Broese van Groenou M. I., Grundy E., 2004, "Living arrangements among older people: An overview of trends in Europe and the USA", Population Trends, 115, pp. 24-34.

VAN IMHOFF E., KEILMAN N. W., 1991, "LIPRO 2.0: An application of a dynamic demographic projection model to household structure in the Netherlands", NIDI CBGS Publications, 23, Amsterdam/Lisse, Swets \& Zeitlinger.

UNITED NATIONS, 2005, Living arrangements of older persons around the world, Department of Economic and Social Affairs, Population division, New York, United Nations, 138 p.

Walker A., Alber J., Guillemard A. M., 1993, Older People in Europe, Social and Economic Policies. The 1993 Report of the European Observatory, Commission of the European Communities, Brussels.

WOLF D.A., 1995, "Changes in the living arrangements of older women: An International study", The gerontologist, 35 (6), pp. 724-731. 


\section{JoËLle Gaymu, Peter EkAMper and GiJs Beets • Who Will be CARING for Europe's} DEPENDENT ELDERS IN 2030?

This article presents demographic projections of the living arrangements of older adults up to 2030 in nine European countries. They are based on country data collected as part of the Felicie project. The aim is to describe how changes in the sociodemographic characteristics of older people (marital situation, health status, existence of surviving children) will affect their living arrangements and thereby modify the form and intensity of their care needs. The results show that over the next 25 years, whatever the overall health trends, the supply of potential family carers, i.e. partners and offspring, will increase and that populations with the greatest need of professional assistance - persons living alone with no available family members or those liable to enter an institution - will grow more slowly than the dependent population in general. However, the ageing of this population, the growing number of elderly men with a dependent spouse and the greater longevity of couples in which both members have disabilities, all point to rapid growth in demand for professional assistance in years to come. These results indicate that policies for managing dependence will need to focus on support for family carers.

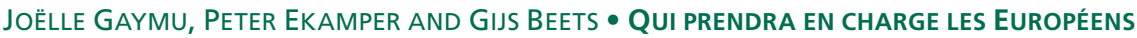 ÂGÉS DÉPENDANTS EN 2030 ?}

Cet article présente les résultats de projections démographiques des modes de vie des personnes dépendantes âgées de 75 ans ou plus, à l'horizon 2030, dans neuf pays européens. Les données nationales ont été collectées dans le cadre du projet Felicie. L'objectif est de décrire comment l'évolution des principales caractéristiques socio-démographiques des personnes âgées (la situation matrimoniale, l'état de santé, avoir ou non un enfant survivant) va changer leurs modes de vie et par-là même les besoins de prise en charge de la dépendance tant dans sa forme que dans son intensité. Les résultats montrent que durant les vingt-cinq prochaines années, quelle que soit l'évolution de l'état de santé, le vivier des aidants familiaux potentiels, composé des conjoints et enfants, va s'élargir et les populations les plus tributaires d'aide professionnelle - personnes vivant seules sans soutien possible de la part d'un descendant ou susceptibles d'entrer en institution - vont croître moins vite que l'ensemble de la population dépendante. Toutefois, le vieillissement de cette population, la croissance de la population masculine confrontée à la dépendance d'une conjointe et la survie plus fréquente de couples dont les deux membres souffrent d'incapacités laissent présager un important surcroît de besoins d'aide d'ordre professionnel. Ces résultats soulignent la nécessité d'orienter prioritairement les politiques de prise en charge de la dépendance vers un soutien aux aidants familiaux.

\section{JoËLle GAYMu, Peter EKAMPER AND GIJS BeETS • ¿QUIÉn ATENDERÁ A los Europeos} MAYORES Y DEPENDIENTES EN 2030?

En este artículo se presentan los resultados de proyecciones demográficas de los modos de vida de las personas dependientes de 75 años de edad o más, al horizonte de 2030, en nueve países europeos. Los datos nacionales fueron recogidos dentro del marco del proyecto Felicie. El objetivo es describir cómo la evolución de las principales características sociodemográficas de las personas mayores (la situación matrimonial, el estado de salud, tener o no un hijo sobreviviente) va a cambiar sus modos de vida y de ahí las necesidades de hacerse cargo de la dependencia tanto en su forma como en su intensidad. Los resultados muestran que durante los veinticinco próximos años, cualquiera que sea la evolución del estado de salud, el vivero de los familiares cuidadores potenciales, compuesto por los cónyuges e hijos, va a ampliarse y las poblaciones más supeditadas a ayuda profesional - personas que viven solas sin sostén posible de un descendiente o que podrían ingresar en una institución - van a crecer menos rápido que el conjunto de la población dependiente. Sin embargo, el envejecimiento de esta población, el crecimiento de la población masculina que se enfrenta con la dependencia de un cónyuge y la sobrevivencia más frecuente de parejas en las que los dos miembros sufren de incapacidades dejan presagiar un importante aumento de necesidades de ayuda de orden profesional. Estos resultados subrayan la necesidad de orientar prioritariamente las políticas de atención de la dependencia hacia un apoyo a los familiares para cuidar.

Joëlle GAYMU, Institut national d'études démographiques, 133 boulevard Davout, 75980 Paris Cedex 20, tel. : 33 (0)1 560621 21, e-mail: gaymu@ined.fr 